\title{
Pengaruh Metode Discovery Learning dan Drill serta Motivasi Belajar terhadap Hasil Belajar Bolavoli siswa Kelas VIII SMPN 1 Kediri
}

\author{
Miftachul Ulum \\ SMPN 1 Kediri \\ mulum23@yahoo.com
}

\begin{abstract}
Abstrak
Berawal dari ketidakpuasan nilai bolavoli yang relative rendah, maka dikembangkan metode pembelajaran Discovery Learning dan drill serta motivasi belajar. Tujuan Penelitian ini adalah untuk mengetahui: adakah pengaruh antara metode discovery learning dengan metode drill terhadap hasil belajar bolavoli; adakah pengaruh motivasi belajar terhadap hasil belajar bolavoli; dan adakah interaksi antara metode Discovery Learning dan metode Drill dengan motivasi belajar terhadap hasil belajar bolavoli pada siswa kelas VIII SMPN 1 Kediri. Metode penelitian ini adalah metode eksperimen. Sampel 134 siswa (4 kelas) dari populasi 342 siswa (10 kelas). Teknik pengumpulan data ini dengan angket motivasi belajar dan tes hasil belajar bolavoli. Teknik analisa data yang digunakan adalah ANAVA. Hasil analisis data untuk hipotesis pertama ditemukan harga $\mathrm{F}$ sebesar 0,379 dengan nilai signifikansi sebesar 0,539 dan untuk hipotesis kedua ditemukan harga $F$ sebesar 5,712 dengan nilai signifikansi sebesar 0,018 serta untuk hipotesis ketiga ditemukan harga $\mathrm{F}$ sebesar 4,232 dengan nilai signifikansi 0,0421. Berdasarkan hasil penelitian dan hasil analisis data, dapat diperoleh kesimpulan: Tidak ada pengaruh antara metode Discovery learning dengan metode Drill terhadap hasil belajar Bolavoli; Ada pengaruh motivasi belajar terhadap hasil belajar Bolavoli; Ada interaksi antara metode Discovery Learning dan metode Drill dengan motivasi belajar terhadap hasil belajar Bolavoli.
\end{abstract}

Kata Kunci: Metode Discovery Learning, Metode Drill, Motivasi, Hasil Belajar

\section{PENDAHULUAN}

Permainan bolavoli di Indonesia berkembang sangat pesat di semua lapisan masyarakat, sehingga timbul klub-klub di kota besar di seluruh Indonesia (kemendikbud, 2014:20). Di Kota Kediri, permainan bolavoli juga berkembang pesat, banyak klub-klub yang bermunculan. Masyarakat rata-rata sudah mengenal dan bahkan pernah memainkannya. Sekolahsekolah hampir setiap tahun mengikuti kompetisi bolavoli dalam rangka seleksi O2SN. Ini berarti pertanda bolavoli sudah dikenal dan memasyarakat pula di kalangan pelajar.

Di SMP Negeri 1 Kediri permainan bola voli sudah dikenal dan bahkan menampung para siswa yang berminat dalam kegiatan ekstra bolavoli. Bahkan bolavoli menjadi salah satu materi yang diajarkan dalam pelajaran PJOK. Namun demikian, hasil belajar bolavoli tidak sebagus dengan perkembangan bolavoli di masyarakat. Bagi guru hal ini menjadi menarik untuk dikaji dan ditindaklanjuti. Untuk itu sebagai seorang guru disamping menguasai materi, juga diharapkan dapat menetapkan dan melaksanakan penyajian materi yang sesuai kemampuan siswa dan kesiapan siswa, sehingga menghasilkan penguasaan materi yang optimal bagi siswa. Artinya guru harus bisa memilih metode pembelajaran yang tepat dan saat kapan kesiapan siswa utnuk menerima materi maka perlu perlu peningkatan motivasi siswa. Dalam masalah ini peneliti ingin membandingkan tingkat keefektifan metode discovery dan metode Drill serta 
pengaruh motivasi belajar terhadap hasil belajar bolavoli.

Metode discovery adalah metode pembelajaran yang mengkondisikan siswa untuk terbiasa menemukan, mencari, mendiskusikan sesuatu yang berkaitan dengan pengajaran (Siadari, 2001:4). Dalam metode pembelajaran discovery siswa lebih aktif dalam memecahkan untuk menemukan sedangkan guru berperan sebagai pembimbing atau memberikan petunjuk cara memecahkan masalah itu.

Sedangkan metode drill ialah suatu teknik yang dapat diartikan sebagai suatu cara mengajar di mana siswa melaksanakan kegiatan-kegiatan latihan, agar siswa memiliki ketangkasan atau ketrampilan yang lebih tinggi dari apa yang telah dipelajari (Roestiyah, 2012:125). Ini berarti program-program latihan yang sudah disiapkan guru harus dilaksanakan selama dalam pembelajaran untuk meningkatkan ketrampilan yang dimiliki.

Dalam hal belajar siswa akan berhasil kalau dalam dirinya sendiri ada kemauan untuk belajar dan keinginan atau dorongan untuk belajar, karena dengan peningkatan motivasi belajar maka siswa akan tergerak, terarahkan sikap dan perilaku siswa dalam belajar. Guru hendaknya membangkitkan motivasi belajar siswa karena tanpa motivasi belajar, hasil belajar yang dicapai akan minimum sekali (Rochman Natawidjaja dan L.J.Moleong, 1979:11). Oleh karena itu agar hasil yang diajarkannya tercapai secara optimal, maka seorang guru harus mampu membangkitkan motivasi belajar siswa. Sejalan dengan pendapat tersebut, menurut Biggs dan Tefler motivasi belajar pada siswa dapat menjadi lemah, lemahnya motivasi atau tiadanya motivasi belajar akan melemahkan kegiatan, sehingga mutu hasil belajar akan menjadi rendah (Dimyati dan Mudjiono, 1994). Oleh karena itu, motivasi belajar pada diri siswa perlu diperkuat terus menerus. Dengan tujuan agar siswa memiliki motivasi belajar yang kuat, sehingga hasil belajar yang diraihnyapun dapat optimal.

Berdasarkan uraian di atas, maka perlu dilakukan suatu penelitian yang bertujuan untuk meningkatkan hasil belajar bola voli melalui metode pembelajaran discovery learning dan metode drill serta motivasi belajar siswa. Dalam penelitian ini peneliti menentukan judul penelitian, "Pengaruh Metode Discovery Learning dan Drill serta Motivasi Belajar terhadap Hasil Belajar Bola Voli pada siswa Kelas VIII SMPN 1 Kediri”.

Adapun tujuan penelitian ini adalah: 1) untuk mengetahui adakah pengaruh antara metode discovery learning dengan metode drill terhadap hasil belajar bola voli pada siswa kelas VIII SMPN 1 Kediri, 2) untuk mengetahui adakah pengaruh motivasi belajar terhadap hasil belajar bola voli pada siswa kelas VIII SMPN 1 Kediri, dan 3) untuk mengetahui adakah interaksi antara metode Discovery Learning dan Drill dengan motivasi belajar terhadap hasil belajar bola voli pada siswa kelas VIII SMPN 1 dan Kediri.

\section{METODE PENELITIAN}

Metode penelitian ini adalah eksperimen dengan menggunakan empat kelas sampel penelitian dan teknik pengambilan sampel adalah cluster sampling. Rancangan penelitian ini dapat digambarkan sebagai berikut:

Tabel 3.1: Rancangan Penelitian Faktorial $2 \times 2$

\begin{tabular}{|l|c|c|}
\hline \multirow{2}{*}{$\begin{array}{l}\text { Motivasi } \\
\text { Belajar (A) }\end{array}$} & \multicolumn{2}{|c|}{$\begin{array}{c}\text { Metode Pembelajaran } \\
\text { (X) }\end{array}$} \\
\cline { 2 - 3 } & $\begin{array}{c}\text { Metode } \\
\text { Discovery } \\
\text { Learning (X1) }\end{array}$ & $\begin{array}{c}\text { Metode Drill } \\
\text { (X2) }\end{array}$ \\
\hline $\begin{array}{l}\text { Motivasi } \\
\text { Belajar } \\
\text { Tinggi (A1) }\end{array}$ & Y1( A1.X1) & Y2( A1.X2) \\
\hline $\begin{array}{l}\text { Motivasi } \\
\text { Belajar } \\
\text { Rendah (A2) }\end{array}$ & $\mathrm{Y} 1(\mathrm{~A} 2 . \mathrm{X} 1)$ & $\mathrm{Y} 2(\mathrm{~A} 2 . \mathrm{X} 2)$ \\
\hline
\end{tabular}

Keterangan:

A $\quad=$ Motivasi Belajar 


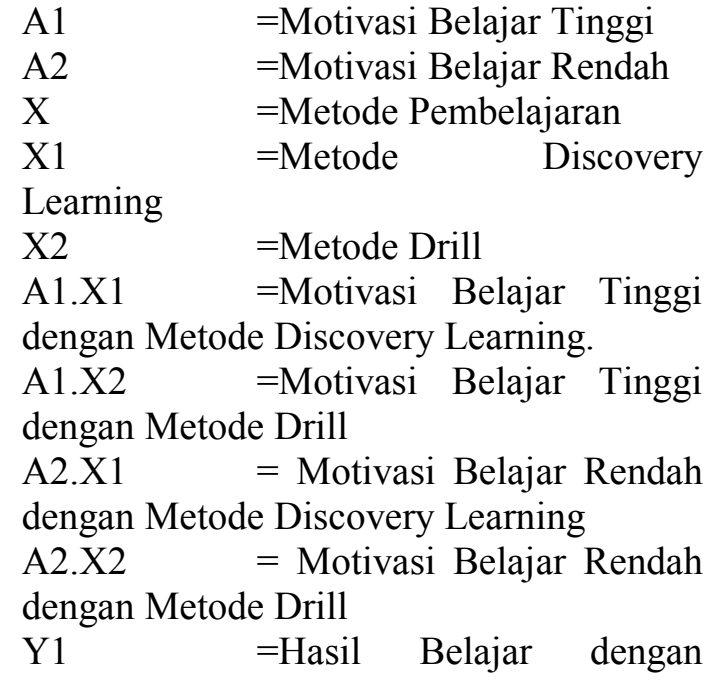

Metode Discovery Learning

Y2 =Hasil Belajar dengan Metode Drill

Populasi adalah wilayah generalisasi yang terdiri atas obyek/subyek yang mempunyai kuantitas dan karakteristik tertentu yang ditetapkan oleh peneliti untuk dipelajari dan ditarik kesimpulan (Sugiono, 2008:35). Di sini yang menjadi populasi adalah semua siswa kelas VIII SMPN 1 Kediri.

Sampel adalah sebagian dari jumlah karakteristik yang dimiliki oleh populasi. Di sini yang menjadi sampel adalah siswa kelas VIII A, VIII D, VIII E dan VIII G SMPN 1 Kediri.

Teknik sampling adalah teknik cluster sampling sebab populasi dibagi dulu atas kelompok berdasarkan area atau cluster, lalu beberapa cluster dipilih sebagai sampel (Siregar, 2014:59). Oleh karena itu dari 20 kelas sebagai popuasi ditarik 4 (empat) kelas sebagai sampel penelitian.

\section{Instrumen Penelitian}

adalah terdiri atas angket 20 soal dan tes hasil belajar 5 soal tes tulis dan 5 soal tes unjuk kerja. Semua instrumen dalam penelitian ini diuji validitas dan reliabilitas dengan menggunakan SPSS 21.

\section{Prosedur Penelitian}

Langkah pertama dalam penelitian ini adalah menguji validitas dan reliabilitas terhadap soal tes penilaian (rubrik penilaian) dan soal angket.

Karena penelitian ini penelitian eksperimental yaitu peneliti memberikan dua perlakuan, yaitu: (1) mengajar menggunakan metode discovery learning pada siswa kelas VIII A dan VIII B, dan (2) mengajar menggunakan metode drill pada siswa kelas VIII E dan VIII G SMPN 1 Kediri.

Setelah kedua perlakuan tersebut selesai, dilakukan ulangan terhadap sampel yang diajar dengan menggunakan metode discovery learning dan yang diajar dengan menggunakan metode drill. Dari dua jenis data penilaian yang diperoleh tersebut dimasukkan ke dalam tabel hasil belajar siswa untuk memudahkan uji statistiknya.

Langkah selanjutnya siswa diberi angket motivasi belajar yang hasilnya kemudian dikelompokkan menjadi dua, yaitu siswa yang memiliki motivasi belajar tinggi dan siswa yang memiliki motivasi belajar rendah, selanjutnya hasil ini dimasukkan ke dalam tabel motivasi belajar.

\section{Teknik Pengumpulan Data}

Teknik pengumpulan data adalah teknik atau cara-cara yang dapat digunakan oleh peneliti untuk mengumpulkan data (Riduwan, 2009:97). Pengumpulan data ini dilakukan dengan:

1. Angket motivasi belajar

Angket adalah teknik pengumpulan data melalui formulirformulir yang berisi pertanyaanpertanyaan yang diajukan secara tertulis pada seseorang atau sekumpulan orang untuk mendapatkan jawaban dan informasi yang diperlukan peneliti. Angket ini dilengkapi dengan 5 option jawaban dan masing-masing option diberi skor sebagai berikut: Sangat Setuju (SS) skor 5, Setuju (S) skor 4, Kurang 
Setuju (KS) skor 3, Tidak Setuju (TS) skor 2 dan Sangat Tidak Setuju (STS) skor 1 .

Untuk menentukan apakah motivasi belajar seorang siswa tinggi atau rendah, maka hasil dari penjumlahan skor yang diperoleh seluruh siswa dirata-rata yang selanjutnya dibandingkan dengan kriteria pada tebel di bawah ini.

Tabel 3.4: Kriteria skor angket Motivasi

\begin{tabular}{|c|c|}
\multicolumn{2}{c}{ Belajar } \\
\hline Kriteria & $\begin{array}{c}\text { Nilai Total } \\
\text { Angket }\end{array}$ \\
\hline Tinggi & $\mathrm{X} \geq$ rata-rata \\
\hline Rendah & $\mathrm{X}<$ rata-rata \\
\hline
\end{tabular}

2. Tes hasil belajar

Tes adalah alat penilaian hasil belajar (Sudjana, 2008:35). Tes ini digunakan untuk menilai dan mengukur pengetahuan dan ketrampilan hasil belajar bola voli sesuai dengan tujuan pendidikan dan pengajaran.

Jenis tes ini meliputi: (1) tes tulis dalam bentuk lima soal obyektif berupa pilihan ganda di mana telah tersedia alternatif jawaban yang dapat dipilih siswa yang dibuat oleh peneliti. Cara pemberian nilai adalah jika subyek menjawab benar, maka tiap butir soal diberi nilai 10. Bila jawaban benar semua nilai 50. Dan, (2) tes unjuk kerja bola voli yang harus diikuti siswa. Setiap siswa yang tampil praktik, teknik yang ditunjukkan diamati lalu dibandingkan dengan lima kriteria yang benar. Bila baik sekali skor 5, baik skor 4, sedang skor 3, cukup skor 2 dan tidak baik skor 1 . Hasil nilai tes unjuk kerja merupakan hasil penjumlahan skor tiap item tes dikalikan 2. Bila unjuk kerja benar semua nilai 50. Sehingga total nilai tes hasil belajar bola voli adalah 100 .

\section{Teknik Analisis Data}

Teknik analisis data yang digunakan adalah teknik analisis varian dua jalan (ANAVA). Analisis varian dua jalan digunakan untuk menguji hipotesis perbandingan lebih dari dua sampel dan setiap sampel terdiri atas dua jenis atau lebih secara bersama-sama (Riduwan, 2009:170). Teknik analisis data dalam penelitian ini, adalah:

1. Uji persyaratan hipotesis

Sebelum data digunakan untuk pengujian hipotesis, perlu dilakukan terlebih dahulu uji normalitas dan uji homogenitas dengan SPSS 21. Pengujian untuk masing-masing hipotesis dilakukan setelah data diketahui berdistribusi normal dan homogen.

a. Uji normalitas

Uji normalitas bertujuan untuk mengetahui sampel berasal dari populasi berdistribusi normal atau tidak. Uji normalitas menggunakan KolmogorovSmirnov yang ada pada SPSS 21 dengan menggunakan taraf signifikan 0,05 .

b. Uji homogenitas

Uji homogenitas digunakan untuk mengetahui apakah kelompok eksperimen dan kelompok kontrol memiliki varians yang sama (homogen) atau tidak. Uji homogenitas menggunakan $\mathrm{Uji}$ Levene's yang ada pada SPSS 21.

\section{Uji Hipotesis}

Uji hipotesis menggunakan Tests of Between-Subjeccts Effects yang ada pada SPSS 21. Peneliti menggunakan SPSS 21 untuk melakukan perhitungan uji analisis varians dua jalur. Perhitungan tersebut digunakan untuk menguji hipotesis 1, 2 dan 3.

\section{HASIL DAN PEMBAHASAN Deskripsi Data}


Deskripsi data tentang tingkat motivasi belajar siswa kelas VIII SMPN 1 Kediri yang diberikan pembelajaran dengan metode Discovery Learning dan metode Drill dengan jumlah sampel 134 siswa disajikan pada tabel 4.1.

Tabel 4.1 Distribusi Frekuensi Motivasi Belajar dari Metode Pembelajaran

\begin{tabular}{|c|c|c|c|c|c|}
\hline \multirow{2}{*}{$\begin{array}{c}\text { Kriteria } \\
\text { Motivas } \\
\text { i }\end{array}$} & \multicolumn{2}{|c|}{$\begin{array}{c}\text { Metode } \\
\text { Discovery } \\
\text { Learning }\end{array}$} & \multicolumn{2}{|c|}{$\begin{array}{c}\text { Metode } \\
\text { Drill }\end{array}$} & \multirow[t]{2}{*}{ Total } \\
\hline & $\begin{array}{c}\mathrm{Jml} \\
\mathrm{h}\end{array}$ & $\%$ & $\mathrm{jml}$ & $\%$ & \\
\hline Tinggi & 27 & $40 \%$ & 35 & $52 \%$ & 62 \\
\hline Rendah & 40 & $60 \%$ & 32 & $48 \%$ & 72 \\
\hline Jumlah & 67 & $\begin{array}{c}100 \\
\%\end{array}$ & 67 & $\begin{array}{c}100 \\
\%\end{array}$ & 134 \\
\hline
\end{tabular}

Sumber: Hasil Perhitungan Distribusi Frekuensi

Dari tabel 4.1 di atas dapat dikatakan bahwa jumlah siswa yang bermotivasi tinggi pada metode pembelajaran Discovery Learning adalah 27 siswa (40\%) dan yang bermotivasi rendah 40 siswa $(60 \%)$. Sedangkan pada metode pembelajaran Drill jumlah siswa yang bermotivasi tinggi adalah 35 siswa (52\%) dan yang bermotivasi rendah 32 siswa (48\%).

Deskripsi data tentang hasil belajar siswa kelas VIII SMPN 1 Kediri yang diberikan pembelajaran dengan metode Discovery Learning dan metode Drill dengan jumlah sampel 134 siswa disajikan pada tabel 4.2.

Tabel 4.2 Distribusi Frekuensi Hasil Belajar dari Metode Pembelajaran

\begin{tabular}{ccc}
\hline \multirow{2}{*}{$\begin{array}{c}\text { Tingkat } \\
\text { Hasil }\end{array}$} & $\begin{array}{c}\text { Metode Pembelajaran } \\
\text { Discovery Learning }\end{array}$ \\
\cline { 2 - 3 } & Jumlah & Persentase \\
\hline $61-70$ & 5 & $7 \%$ \\
\hline $71-80$ & 30 & $45 \%$ \\
\hline $81-90$ & 31 & $46 \%$ \\
\hline $91-100$ & 1 & $1 \%$ \\
\hline Jumlah & 67 & $100 \%$ \\
\hline \multicolumn{3}{|}{ Metode Pembelajaran } \\
Dingkat \\
Hasil
\end{tabular}

\begin{tabular}{ccc}
\hline & Jumlah & Persentase \\
\hline $61-70$ & 6 & $9 \%$ \\
\hline $71-80$ & 26 & $39 \%$ \\
\hline $81-90$ & 34 & $51 \%$ \\
\hline $91-100$ & 1 & $1 \%$ \\
\hline Jumlah & 67 & $100 \%$ \\
\hline
\end{tabular}

Sumber: Hasil Perhitungan Distribusi Frekuensi

\% Dari tabel 4.2 di atas dapat dikatakan bahwa pada metode pembelajaran Discovery Learning jumlah siswa yang hasibbelajar antara 61-70 sebanyak 5 siswa $(70 \% 0$ antara $71-80$ sebanyak 30 siswa (45\%) antara 81-90 sebanyak 31 siswa (460\%)\% antara 91-100 sebanyak 1 siswa (1\%). Sedangkan pada metode pembelajaran Drill jumlah siswa yang hasil belajar antara 61-70 sebanyak 6 siswa (9\%), antara 71-80 sebanyak 26 siswa (39\%), antara 81-90 sebanyak 34 siswa (51\%), antara 91-100 sebanyak 1 siswa (1\%).

Untuk data lebih lanjut tentang motivasi dan hasil belajar siswa kelas VIII SMPN 1 Kediri dapat dilihat pada lampiran.

\section{Uji Prasyarat Analisis}

\section{Uji Normalitas}

Hasil uji normalitas data hasil belajar siswa kelas VIII SMPN 1 Kediri yang menggunakan metode Discovery Learning dan metode Drill disajikan pada tabel 4.3.

Tabel 4.3 Hasil Uji Normalitas Hasil Belajar dari Metode Pembelajaran 


\begin{tabular}{|c|c|c|c|}
\hline \multicolumn{4}{|c|}{ One-Sample Kolmogorov-Smirnov Test } \\
\hline \multicolumn{3}{|c|}{\begin{tabular}{|l|l|} 
Discov \\
ery \\
Learnin \\
$\mathrm{g}$
\end{tabular}} & Drill \\
\hline \multicolumn{2}{|c|}{$\mathrm{N}$} & 67 & 67 \\
\hline \multirow[b]{2}{*}{$\begin{array}{l}\text { Normal } \\
\text { Parametersa } \\
\text {,b }\end{array}$} & Mean & 80,42 & 80,24 \\
\hline & $\begin{aligned} & \text { Std. } \\
& \text { Devi } \\
& \text { ation }\end{aligned}$ & 6,301 & 5,641 \\
\hline \multirow{3}{*}{\begin{tabular}{|l|} 
Most \\
Extreme \\
Differences
\end{tabular}} & Absolute &, 103 &, 145 \\
\hline & Positive & ,085 & ,088 \\
\hline & Negative &,- 103 &,- 145 \\
\hline \multicolumn{2}{|c|}{ Kolmogorov-Smirnov Z } &, 845 & 1,186 \\
\hline \multicolumn{2}{|c|}{ Asymp. Sig. (2-tailed) } & ,473 &, 120 \\
\hline \multicolumn{4}{|c|}{$\begin{array}{l}\text { a. Test distribution is Normal. } \\
\text { b. Calculated from data. } \\
\text { Sumber: Hasil Perhitungan Uji } \\
\text { Normalitas }\end{array}$} \\
\hline
\end{tabular}

Untuk uji normalitas data hasil belajar siswa kelas VIII SMPN 1 Kediri dengan metode Discovery Learning pada tabel 4.3 ternyata signifikansinya lebih besar dari 0,05 yaitu 0,473 berarti hasil belajar siswa dengan metode Discovery Learning berdistribusi normal.

Untuk uji normalitas data hasil belajar siswa kelas VIII SMPN 1 Kediri dengan menggunakan metode pembelajaran Drill pada tabel 4.3 ternyata signifikansinya lebih besar dari 0,05 yaitu 0,120 berarti hasil belajar siswa dengan metode pembelajaran Drill berdistribusi normal.

Hasil uji normalitas data hasil belajar siswa kelas VIII SMPN 1 Kediri yang memiliki motivasi tinggi dan siswa yang memiliki motivasi rendah disajikan pada tabel 4.4 .

Tabel 4.4 Hasil Uji Normalitas Hasil Belajar dari Motivasi Belajar

\begin{tabular}{|l|l|l|}
\hline One-Sample Kolmogorov-Smirnov Test \\
\hline & Hasil & Hasil \\
& Belajar & Belajar \\
& Siswa & Siswa \\
& yang & yang \\
& Bermotiva & Bermotiv \\
& si Tinggi & asi \\
& Rendah \\
\hline
\end{tabular}

\begin{tabular}{|c|c|c|}
\hline $\mathrm{N}$ & 62 & 72 \\
\hline Normal Mean & 81,58 & 79,25 \\
\hline \begin{tabular}{l|l}
$\begin{array}{l}\text { Paramete } \\
\mathrm{rs}^{\mathrm{a}, \mathrm{b}}\end{array}$ & $\begin{array}{l}\text { Std. } \\
\text { Deviation }\end{array}$ \\
\end{tabular} & 5,693 & 6,009 \\
\hline \begin{tabular}{|l|l|} 
Most & Absolute \\
\cline { 2 - 2 }
\end{tabular} & , 148 &, 147 \\
\hline Extreme Positive & ,081 &, 059 \\
\hline \begin{tabular}{|l} 
Differenc \\
es
\end{tabular}$\quad$ Negative &,- 148 &,- 147 \\
\hline $\begin{array}{r}\text { Kolmogorov- } \\
\text { Smirnov Z } \\
\end{array}$ & 1,169 & 1,246 \\
\hline $\begin{array}{c}\text { Asymp. Sig. (2- } \\
\text { tailed) } \\
\end{array}$ & , 130 & ,089 \\
\hline
\end{tabular}

Sumber: Hasil Perhitungan Uji Normalitas

Untuk uji normalitas data hasil belajar siswa kelas VIII SMPN 1 Kediri dengan motivasi belajar tinggi pada tabel 4.4 ternyata signifikansinya lebih besar dari 0,05 yaitu 0,130 berarti hasil belajar siswa dengan motivasi belajar tinggi berdistribusi normal.

Untuk uji normalitas data hasil belajar siswa kelas VIII SMPN 1 Kediri dengan motivasi belajar rendah pada tabel 4.4 ternyata signifikansinya lebih besar dari 0,05 yaitu 0,089 berarti hasil belajar siswa dengan motivasi belajar rendah berdistribusi normal.

2. Uji Homogenitas

Hasil uji homogenitas data hasil belajar siswa kelas VIII SMPN 1 Kediri yang menggunakan metode pembelajaran Discovery Learning dan metode Drill disajikan pada tabel 4.5.

Tabel 4.5 Hasil Uji Homogenitas Hasil

Belajar dari Metode Pembelajaran

\begin{tabular}{|c|c|c|c|}
\hline F & df1 & df2 & Sig. \\
\hline 689 & 1 & 132 &, 408 \\
\hline
\end{tabular}

Tests the null hypothesis that the error variance of the dependent variable is equal across groups.

a. Design: Intercept + Metode

Sumber: Hasil Perhitungan Uji

Homogenitas

Untuk uji homogenitas data hasil belajar siswa kelas VIII SMPN 1 Kediri dengan metode pembelajaran Discovery 
Learning dan Metode Drill pada tabel 4.5 ternyata siginifikansinya lebih besar dari 0,05 yaitu 0,408 berarti data hasil belajar siswa dengan metode pembelajaran Discovery Learning dan metode Drill homogen.

Hasil uji homogenitas data hasil belajar siswa kelas VIII SMPN 1 Kediri dengan motivasi belajar tinggi dan siswa dengan motivasi belajar rendah disajikan pada tabel 4.6.

Tabel 4.6 Hasil Uji Homogenitas Hasil Belajar dari Motivasi Belajar

\begin{tabular}{|c|c|c|c|}
\hline F & df1 & df2 & Sig. \\
\hline, 117 & 1 & 132 &, 732 \\
\hline
\end{tabular}

Tests the null hypothesis that the error variance of the dependent variable is equal across groups.

a. Design: Intercept + Motivasi

Sumber: Hasil Perhitungan Uji Homogenitas

Untuk uji homogenitas data hasil belajar siswa kelas VIII SMPN 1 Kediri dengan motivasi belajar tinggi dan siswa dengan motivasi belajar rendah pada tabel 4.6 ternyata signifikansinya lebih besar dari 0,05 yaitu 0,732 berarti data hasil belajar siswa dengan motivasi belajar tinggi dan siswa dengan motivasi belajar rendah homogen.

\section{Uji Hipotesis}

Pada bagian ini akan dibahas tentang uji hipotesis mengenai perbedaan metode discovery learning dan metode drill terhadap hasil belajar Bola Voli pada siswa Kelas VIII SMPN 1 Kediri. Kemudian akan diuraikan juga tentang uji hipotesis mengenai perbedaan antara siswa yang memiliki motivasi belajar tinggi dan motivasi belajar rendah terhadap hasil belajar Bola Voli pada siswa Kelas VIII SMPN 1 Kediri. Dan yang terakhir mengenai pengujian hipotesis interaksi antara metode discovery learning dan metode drill dengan motivasi belajar terhadap hasil belajar Bola Voli pada siswa Kelas VIII SMPN 1 Kediri.

Berikut merupakan hasil perhitungan uji analisis varians dua jalur untuk menguji hipotesis 1, 2 dan 3 yang menggunakan SPSS 21 diasjikan pada tabel 4.7.

Tabel 4.7 Hasil Analisis Anova Dua Jalur

\begin{tabular}{|c|c|c|c|c|c|}
\hline \multicolumn{6}{|c|}{ Dependent Variable: HASIL BELAJAR } \\
\hline Source & \begin{tabular}{|c|} 
Type III \\
Sum of \\
Squares
\end{tabular} & df & $\begin{array}{l}\text { Mean } \\
\text { Square }\end{array}$ & $\mathrm{F}$ & Sig. \\
\hline $\begin{array}{l}\text { Corrected } \\
\text { Model }\end{array}$ & $331,011^{\mathrm{a}}$ & 3 & 110,337 & 3,267 & 023 \\
\hline Intercept & $\begin{array}{c}851773,69 \\
6\end{array}$ & 1 & $\begin{array}{c}851773,6 \\
96 \\
\end{array}$ & $\begin{array}{c}25220 \\
, 255\end{array}$ & 000 \\
\hline METODE & 12,794 & 1 & 12,794 & ,379 & ,539 \\
\hline KMOT & 192,921 & 1 & 192,921 & 5,712 & 018 \\
\hline $\begin{array}{l}\text { METODE } \\
* \text { KMOT }\end{array}$ & 142,945 & 1 & 142,945 & 4,232 & ,042 \\
\hline Error & 4390,542 & 130 & 33,773 & & \\
\hline Total & $\begin{array}{c}869376,00 \\
0\end{array}$ & 134 & & & \\
\hline $\begin{array}{l}\text { Corrected } \\
\text { Total }\end{array}$ & 4721,552 & 133 & & & \\
\hline
\end{tabular}

a. R Squared $=, 070$ (Adjusted R Squared $=, 049$ )

Sumber: Hasil Perhitungan Analisis Anova

Dua Jalur

Pengujian Hipotesis Pertama

Untuk uji hipotesis pertama berbunyi:

Ho : Tidak ada perbedaan antara metode discovery learning dengan metode drill terhadap hasil belajar Bola Voli pada siswa Kelas VIII SMPN 1 Kediri.

$\mathrm{Ha}$ : Ada perbedaan antara metode discovery learning dengan metode drill terhadap hasil belajar Bola Voli pada siswa Kelas VIII SMPN 1 Kediri.

Kriteria uji yang digunakan adalah apabila probabilitas (signifikansi) lebih besar atau sama dengan 0,05, maka Ho diterima, sedangkan jika sebaliknya yaitu jika probabilitas (signifikansi) lebih kecil dari 0,05 maka Ho ditolak (Ha diterima).

Berdasarkan tabel 4.7 diperoleh nilai $F$ hitung sebesar 0,379 dengan tingkat signifikansi sebesar 0,539. Ini menunjukkan bahwa Ho diterima (Ha ditolak) artinya tidak ada perbedaan antara 
metode discovery learning dengan metode drill terhadap hasil belajar Bola Voli pada siswa Kelas VIII SMPN 1 Kediri.

Pengujian Hipotesis Kedua

Untuk uji hipotesis kedua berbunyi:

Ho : Tidak ada perbedaan antara siswa yang memiliki motivasi belajar tinggi dengan motivasi belajar rendah terhadap hasil belajar Bola Voli pada siswa Kelas VIII SMPN 1 Kediri.

$\mathrm{Ha}$ : Ada perbedaan antara siswa yang memiliki motivasi belajar tinggi dengan motivasi belajar rendah terhadap hasil belajar Bola Voli pada siswa Kelas VIII SMPN 1 Kediri.

Kriteria uji yang digunakan adalah apabila probabilitas (signifikansi) lebih besar atau sama dengan 0,05, maka Ho diterima, sedangkan jika sebaliknya yaitu jika probabilitas (signifikansi) lebih kecil dari 0,05 maka Ho ditolak (Ha diterima).

Berdasarkan tabel 4.7 diperoleh $\mathrm{F}$ hitung sebesar 5,712 dengan tingkat signifikansi sebesar 0,018. Ini menunjukkan bahwa Ho ditolak (Ha diterima) artinya ada perbedaan antara siswa yang memiliki motivasi belajar tinggi dengan motivasi belajar rendah terhadap hasil belajar Bola Voli pada siswa Kelas VIII SMPN 1 Kediri.

Pengujian Hipotesis Ketiga

Untuk uji hipotesis ketiga berbunyi:

Ho : Tidak ada interaksi antara metode discovery learning dan metode drill dengan motivasi belajar terhadap hasil belajar Bola Voli pada siswa Kelas VIII SMPN 1 Kediri.

$\mathrm{Ha}$ : Ada interaksi antara metode discovery learning dan metode drill dengan motivasi belajar terhadap hasil belajar Bola Voli pada siswa Kelas VIII SMPN 1 Kediri.

Kriteria uji yang digunakan adalah apabila probabilitas (signifikansi) lebih besar atau sama dengan 0,05, maka Ho diterima, sedangkan jika sebaliknya yaitu jika probabilitas (signifikansi) lebih kecil dari 0,05 maka Ho ditolak (Ha diterima).

Berdasarkan tabel 4.7 diperoleh $\mathrm{F}$ hitung sebesar 4,232 dengan nilai signifikansi sebesar 0,042 dimana lebih kecil dari 0,05, maka Ho ditolak artinya ada interaksi antara metode discovery learning dan metode drill dengan motivasi belajar terhadap hasil belajar Bola Voli pada siswa Kelas VIII SMPN 1 Kediri.

\section{PEMBAHASAN}

\section{Pembahasan Hipotesis Pertama}

Hipotesis pertama pada tesis ini berbunyi tidak ada perbedaan antara metode Discovery Learning dengan metode Drill terhadap hasil belajar Bola Voli pada siswa Kelas VIII SMPN 1 Kediri. Dari hasil analisis statistik menggunakan program SPSS for windows 21 diperoleh nilai $F$ hitung sebesar 0,379 dengan tingkat signifikansi sebesar 0,539 dimana lebih besar dari taraf nyata $0,05 \quad(5 \%)$ ini menunjukkan bahwa Ho diterima (Ha ditolak) artinya tidak ada perbedaan antara metode Discovery Learning dengan metode Drill terhadap hasil belajar Bola Voli pada siswa Kelas VIII SMPN 1 Kediri.

Dalam hal ini dapat dijelaskan sebagai berikut. Pembelajaran metode Discovery Learning (Discovery) maupun pembelajaran metode Drill dari segi efektifitas tidak ada perbedaan pengaruh pada hasil belajar bolavoli, antara keduanya memberikan fektifitas yang sama. Dalam pembelajaran cara penyampaian metode Discovery Learning seperti yang disampaikan Sardiman (2005:145) bahwa guru harus dapat membimbing dan mengarahkan kegiatan belajar siswa sesuai dengan tujuan. Dan dipertegas lagi oleg Syah (2004:244) bahwa ada beberapa 
prosedur dalam proses pembelajaranya, yaitu: 1) Stimulation, 2) Problem Statemen, 3) Data collection, 4) Data Processing, 5) Verification, dan 6) Generalization. Sedangkan cara metode Drill adalah suatu cara mengajar dimana siswa melaksanakan kegiatan-kegiatan latihan, agar siswa memiliki ketangkasan atau ketrampilan yang lebih tinggi dari apa yang telah dipelajari (www.tuanguru.com). Selanjutnya menurut Sudjana (1991) bahwa ciri yang khas dari metode ini adalah kegiatan berupa pengulangan yang berkalikali dari suatu hal yang sama. Dengan kedua cara itu masing-masing metode mempunyai kelebihan, kelemahan dan kesamaan. Kesamaan yang tampak adalah keduanya berdasarkan faham konstruktivisme, sama-sama membangun pemahaman konsep dengan cara mengkonstruksi pengalaman demi pengalaman yang didapat (sesuai dengan faham konstruktivisme) selama dalam pembelajaran dan peran guru selalu membimbing dan mengarahkan kegiatan belajar siswa sesuai dengan tujuan. Dan kesamaan berikutnya, keduanya betul-betul melibatkan aktifitas siswa (metode Discovery menuntut siswa aktif dan metode Drill menuntut siswa disiplin). Namun, apabila dilihat dari nilai rata-rata hasil belajar, metode Discovery Learning lebih unggul daripada metode Drill.

\section{Pembahasan Hipotesis Kedua}

Hipotesis kedua pada tesis ini berbunyi ada perbedaan antara siswa yang memiliki motivasi belajar tinggi dengan motivasi belajar rendah terhadap hasil belajar Bola Voli pada siswa Kelas VIII SMPN 1 Kediri. Dari hasil analisis statistik menggunakan program SPSS windows 21 diperoleh nilai $\mathrm{F}$ hitung sebesar 5,712 dengan tingkat signifikansi sebesar 0,018. Ini menunjukkan bahwa Ho ditolak (Ha diterima) artinya ada perbedaan antara siswa yang memiliki motivasi belajar tinggi dengan motivasi belajar rendah terhadap hasil belajar Bola Voli pada siswa Kelas VIII SMPN 1 Kediri.
Dalam hal ini dapat dijelaskan sebagai berikut. Menurut Mc. Donald, motivasi belajar adalah suatu perubahan tenaga di dalam diri seseorang (pribadi) yang ditandai dengan timbulnya perasaan dan reaksi untuk mencapai tujuan (Nashar, 2004:39).

Bila kegiatan telah timbul maka akan muncul perasaan-perasaan terhadap apa yang dihadapinya, dan perasaan yang muncul tersebut merupakan jembatan sebagai upaya mencapai tujuan akhir. Suatu tujuan itu dapat dirumuskan dan ditentukan karena adanya kebutuhan.

Menurut Mulyana (2002:25) ada beberapa prinsip yang dapat digunakan untuk meningkatkann motivasi siswa, diantaranya: 1) siswa akan belajar lebih giat apabila topik yang dipelajarinya menarik dan berguna bagi diri siswa, 2) tujuan pembelajaran harus disusun dengan jelas dan diinformasikan kepada siswa sehingga mereka mengetahui tujuan belajar, 3) siswa harus selalu diberi tahu tentang hasil belajar yang telah diperolehnya, 4) memberikan pujian dan hadiah lebih baik daripada hukuman, namun sewaktu-waktu hukuman juga perlu diberikan, 5) memanfaatkan sikap-sikap, cita-cita dan rasa ingin tahu siswa, 6) usahakan selalu memperhatikan perbedaan individual siswa, misalnya perbedaan kemampuan, latar belakang dan sikap terhadap sekolah atau subyek tertentu, 7) usahakan untuk memenuhi kebutuhan siswa dengan jalan memperhatikan kondisi fisik siswa, memberikan rasa aman, menunjukkan bahwa guru memperhatikan mereka, mengatur pengalaman belajar sedemikian rupa sehingga setiap siswa pernah memperoleh pengalaman, serta mengarahkan pengalaman belajar kearah keberhasilan, sehingga mencapai hasil belajar yang tinggi dan mempunyai kepercayaan diri.

Dalam proses pembelajaran di kelas tentunya ada perbedaan motivasi belajar yang dimiliki oleh setiap siswa, ada siswa dengan motivasi belajar yang tinggi, ada pula yang siswa dengan motivasi belajar 
yang rendah. Perbedaan motivasi belajar siswa ini tentunya berpengaruh pada pencapaian tujuan pembelajaran setiap siswa, sehingga ada pengaruh motivasi belajar terhadap hasil belajar Bola Voli pada siswa Kelas VIII SMPN 1 Kediri.

\section{Pembahasan Hipotesis Ketiga}

Hipotesis ketiga pada tesis ini berbunyi ada interaksi antara metode Discovery Learning dan metode Drill dengan motivasi belajar terhadap hasil belajar Bola Voli pada siswa Kelas VIII SMPN 1 Kediri. Dari hasil analisis statistik menggunakan program SPSS for windows 21 diperoleh nilai $\mathrm{F}$ hitung sebesar 4,232 dengan nilai signifikansi sebesar 0,042 dimana lebih kecil dari 0,05, maka Ho ditolak artinya ada interaksi antara metode Discovery Learning dan metode Drill dengan motivasi belajar terhadap hasil belajar Bola Voli pada siswa Kelas VIII SMPN 1 Kediri.

Dalam hal ini dapat dijelaskan sebagai berikut. Adanya interaksi antara metode Discovery Learning dan metode Drill dengan motivasi belajar terhadap hasil belajar Bola Voli dapat diketahui setelah perlakuan pembelajaran kemudian diberikan instrumen tes hasil belajar Bola Voli serta instrumen angket motivasi belajar.

Hasil belajar siswa dipengaruhi oleh dua faktor utama, yakni faktor dari dalam diri siswa dan faktor yang datang dari luar diri siswa atau faktor lingkungan. Faktor dari dalam diri siswa terutama menyangkut kemampuan yang dimiliki siswa. Faktor ini besar sekali pengaruhnya terhadap hasil belajar yang akan dicapai siswa. Clark mengungkapkan bahwa hasil belajar siswa di sekolah 70\% dipengaruhi oleh kemampuan siswa dan 30\% dipengaruhi lingkungan (Sudjana, 1999:50). Berkaitan dengan faktor dari dalam diri siswa, selain faktor kemampuan, ada juga faktor lain yaitu motivasi, minat, perhatian, sikap, kebiasaan belajar, ketekunan, kondisi sosial ekonomi, kondisi fisik dan psikis. Salah satu faktor lingkungan yang paling dominan mempengaruhi hasil belajar adalah kualitas pengajaran. Yang dimaksud kualitas pengajaran adalah tinggi rendahnya atau efektif tidaknya proses pembelajaran dalam mencapai tujuan instruksional. Pendapat ini sejalan dengan teori belajar di sekolah (Theory of school learning) dari Bloom, bahwa ada tiga variabel utama dalam teori belajar di sekolah, yaitu karakteristik individu, kualitas pengajaran dan hasil belajar siswa.

Penggunaan metode Discovery Learning dengan kelebihannya yang sudah diuraikan diyakini dapat memberikan dorongan pada siswa untuk belajar lebih baik, karena pada metode ini dengan pengawasan dan bimbingan guru, siswa secara aktif berusaha sendiri untuk belajar berlatih memainkan bola voli dan hasil belajar ini secara langsung akan diapresiasi dan dievaluasi. Dengan menampilkan hasil belajar inilah siswa termotivasi untuk berusaha bisa latihan dengan baik. Begitu pula penggunaan metode Drill dengan kelebihannya yang sudah diuraikan diyakini dapat memberikan dorongan pada siswa untuk belajar lebih baik, karena pada metode ini tahap demi tahap siswa dituntut aktif mengikuti petunjuk setiap pada sajian sub-sub materi. Pada tahap akhir siswa diminta untuk menampilkan dengan memainkan bola voli dan hasil belajarnya secara langsung diapresiasi dan dievaluasi. Dengan cara belajar seperti ini, maka siswa termotivasi belajar lebih baik.

Dari penjelasan tersebut di atas tergambarkan bahwa ada interaksi antara metode Discovery Learning dan metode Drill dengan motivasi belajar terhadap hasil belajar Bola Voli pada siswa Kelas VIII SMPN 1 Kediri.

\section{SIMPULAN DAN SARAN}

Berdasarkan hasil pembahasan pada penelitian tentang "Pengaruh Metode Discovery Learning dan Metode Drill serta Motivasi Belajar terhadap Hasil Belajar Bola Voli Siswa Kelas VIII SMPN 1 Kediri” dapat disimpulkan sebagai berikut: 
1. Tidak ada pengaruh antara metode discovery learning dengan metode drill terhadap hasil belajar Bola Voli pada siswa Kelas VIII SMPN 1 Kediri.

2. Ada pengaruh motivasi belajar terhadap hasil belajar Bola Voli pada siswa Kelas VIII SMPN 1 Kediri.

3. Ada interaksi antara metode discovery learning dan metode drill dengan motivasi belajar terhadap hasil belajar Bola Voli pada siswa Kelas VIII SMPN 1 Kediri.

\section{UCAPAN TERIMA KASIH}

Dengan selesainya karya ilmiah ini, terima kasih, kepada:

1. Ibu Yayuk S. Cahyaningsih, S.Pd., M.M., selaku Kepala SMPN 1 Kediri yang telah memberikan izin untuk melakukan penelitian.

2. Teman sejawat yang membantu melakukan penelitian.

3. Semua pihak yang telah mendukung dalam penyusunan karya ilmiah ini.

Semoga Allah SWT memberikan balasan yang setimpal atas segala amal kebaikannya. Aamiin.

DAFTAR PUSTAKA

Dimyati dan Mudjiono. 1994. Belajar dan Pembelajaran.Jakarta: Depdikbud.

http://www.tuanguru.com/2012/08/penerapanmetode-drill.html". Diunduh tanggal, 5 mei 2015 Pk. 17.15 WB).

Kemendikbud. 2014. Pendidikan Jasmani, Olahraga dan Kesehatan SMP/MTs
Kelas VII. Jakarta: Kementerian Pendidikan dan Kebudayaan.

Mulyana, Dedy. 2002. Ilmu Komunikasi serta Pengantar. Bandung: PT. Remaja Rosdakarya.

Natawidjaja, Rochman dan Moloeng, L.J. 1979. Psikologi Pendidikan untuk SPG. Jakarta: Mutiara Sinar.

Nashar. 2004. Peranan Motivasi dan Kemampuan Awal dalam Kegiatan Pembelajaran. Jakarta: Delia Press.

Riduwan. 2009. Metode dan Teknik Menyusun Proposal Penelitian. Bandung: Alfabeta.

Roestiyah. 2012. Strategi Belajar Mengajar. Jakarta: Rineka Cipta.

Sardiman, A.M. 2005. Interaksi dan Motivasi Belajar Mengajar. Jakarta: Rajawali Press.

Siadari. 2001. Teori Metode Pembelajaran. (Diakses).

Eprints.uny.ac.id/7544/1/p\%20\%2023.p df.

Siregar, Syofian. 2014. Statistik Parametrik untuk Penelitian Kuantitatif. Jakarta: Bumin Aksara.

Sudjana, Nana. 1991. Dasar-Dasar Proses Belajar Mengajar. Bandung: Sinar Baru.

Sudjana, Nana. 1999. Penilaian Hasil Proses Belajar Mengajar. Bandung: PT. Remaja Rosdakarya

Sudjana, Nana. 2008. Penilaian Hasil Proses Belajar Mengajar. Bandung: PT. Remaja Rosdakarya.

Sugiyono. 2008. Metode PenelitianKuantitatif Kualitatif dan $R \& D$. Bandung: Alfabeta.

Syah, Muhibbin. 2004. Psikologi Pendidikan dengan Pendekatan Baru. Bandung PT. Remaja Rosdakarya. 